\title{
PENGARUH KOMBINASI EKSTRAK JERUK BRASTAGI DAN WORTEL PER ORAL SEBELUM AKTIVITAS FISIK TERHADAP PENURUNAN KADAR MDA PLASMA MENCIT SETELAH AKTIVITAS FISIK
}

\author{
Nurvidya Rachma Dewi', Ambrosius Purba ${ }^{2}$, Beltasar Tarigan ${ }^{3}$ \\ ${ }^{1}$ Magister Ilmu Kedokteran Dasar, Fakultas Kedokteran, Universitas Padjadjaran \\ ${ }^{2}$ Departemen Anatomi, Fisiologi dan Biologi Sel, Fakultas Kedokteran, Universitas Padjadjaran \\ ${ }^{3}$ Fakultas Pendidikan Olahraga dan Kesehatan, Universitas Pendidikan Indonesia
}

Abstract

Aerobic metabolism in the cellular level generates free radicals. Under normal condition, there's balance between free radicals and endogenous antioxidants. Excessive amount of free radicals impair DNA, protein, fat, etc. The level of free radicals can be known by measuring plasma malondialdehyde level. Combination of Brastagi's oranges and carrots juice as exogenous antioxidants supplementation expected to decrease free radicals level. The aim of this study is to investigate the difference of plasma MDA level during several time intervals on mice which is given and not given combination of Brastagi's oranges and carrots juice before physical activity using mice's treadmill for 20 minutes. The research method used in this study is an experimental laboratory study. The objects of this study are 40 mice (mus musculus), white colored, male, weighting 25-30 grams, which is randomly chosen. The objects are divided into 2 groups, Group A : 20 mice (given combination of Brastagi's oranges and carrots juice before physical activity using mice's treadmill) and group $B: 20$ mice (not given combination of Brastagi's oranges and carrots juice before physical activity using mice's treadmill). Group A are divided into 5 subgroups: A1 (measurement of plasma MDA level at 0 minute after treadmill), A2 (measurement of plasma MDA level at 15 minutes after treadmill), and A3 (measurement of plasma MDA level at 30 minutes after treadmill), A4 (measurement of plasma MDA level at 60 minutes after treadmill), and A5 (measurement of plasma MDA level at 240 minutes after treadmill). The same procedures are employed for the group B. Plasma MDA level measured after doing physical activity using mice treadmill. The homogenity of the result then was tested using Levene's test and the normality of the result was tested using Kolmogorov-smirnov test ( $p>0.05)$. Further, the data was analyzed using independent t-test $(p \leq 0.05)$, one-way ANOVA $(p \leq 0.05)$ then Duncan's test were used. The results reveal significant lowering plasma MDA concentration in mice receiving combination of Brastagi's oranges and carrots juice before physical activity, which is measured during several time intervals: 0,15,30,60, and 240 minutes after physical activity than in mice not receiving combination of Brastagi's oranges and carrots juice before physical activity. The MDA level differences between groups which is given and not given combination of Brastagi's orange and carrots juice before physical activity measured during several intervals are $11,44 \%(0,8920$ vs 1,0071) measured 0 minute after physical activity, $15,47 \%(0,7902$ vs 0,9348) measured 15 minutes after physical activity, $14,42 \%(0,7473$ vs 0,8732) measured 30 minutes after physical activity, 11,35\% (0,6696 vs 0,7554) measured 60 minutes after physical activity, and 13,60\% (0,5786 vs 0,6696) measured 240 minutes after physical activity. The conclusion of the study suggested that combination of Brastagi's orange and carrots juice supplementation has lowering effect toward plasma MDA level measured during several time intervals.

Keywords : combination of Brastagi's oranges and carrots juice, free radicals, Mice, plasma malondialdehyde (MDA)

Korespondensi: Nurvidya Rachma Dewi, E-mail: nurvidya487@gmail.com, Departemen Anatomi Fisiologi dan Biologi Sel, Fakultas Kedokteran Universitas Padjadjaran. Jalan Raya Jatinangor Km 21, Sumedang, Jawa Barat, Indonesia. 


\section{PENDAHULUAN}

Metabolisme aerobik intensitas tinggi yang terdapat di dalam sel akan menghasilkan radikal bebas dengan jumlah yang sangat tergantung dari berbagai faktor. Pada keadaan normal, radikal bebas diproduksi dalam sel dan kadarnya akan meningkat pada saat aktivitas fisik dengan suasana aerobik (Papas,1999).Oksigen yang terlibat dalam proses metabolisme ini dapat bereaksi dengan substrat tertentu yang akan menghasilkan senyawa tidak stabil yang dikenal dengan nama radikal bebas atau oksidan. Oksidan dapat menyebabkan kerusakan pada DNA, protein, serta lipid (Whitney, 2005). Oksidan yang terbentuk tidak akan menjadi masalah selama jumlahnya seimbang dengan antioksidan dalam tubuh.

Pada keadaan aktivitas fisik dengan intensitas tinggi dalam suasana metabolisme aerobik, terjadi peningkatan konsumsi oksigen untuk memenuhi kebutuhan tubuh. Oksigen yang dikonsumsi oleh sel tidak semua dapat direduksi secara sempurna, sebagian akan mengalami kebocoran pada tahap tertentu dari rantai transpor elektron dan kemudian keluar dari jalur respirasi serta berubah menjadi radikal bebas (Whyte, 2005). Radikal bebas yang ditimbulkan dapat berupa Reactive Oxygen Species (ROS). ROS dapat bereaksi dengan senyawa lemak pada membran sel, yang selanjutnya akan mengalami reaksi peroksidasi lipid, dan kemudian akan menghasilkan senyawa malondialdehid (MDA). Jumlah oksidan yang terbentuk akan mengalami peningkatan yang cukup besar sehingga dapat menyebabkan ketidakseimbangan antara antioksidan dengan jumlah oksidan yang terbentuk di dalam sel. Jumlah oksidan dan antioksidan yang tidak seimbang akan menimbulkan suatu stres oksidatif (Papas, 1999). Kondisi ini terjadi karena ada peningkatan konsumsi oksigen ke dalam sel otot untuk memenuhi kebutuhan proses metabolisme sel otot yang pada akhirnya akan meningkatkan produksi superoksida. Superoksida akan mengakibatkan terganggunya komposisi asam lemak membran sel sehingga menyebabkan terjadinya suatu kebocoran enzim dan faktor kemotaksis akan menyebabkan sel menjadi rusak baik secara fungsional maupun struktural (Papas, 1999). Pada prakteknya terjadi kesulitan mengukur kadar radikal bebas yang terbentuk pada waktu melakukan aktivitas fisik aerobik (Ji, 1999). Hal ini dikarenakan sifat senyawa tersebut yang sangat reaktif dan dapat cepat berubah menjadi senyawa lain. Oleh karena itu dilakukan pendekatan lain untuk mengukur kadar radikal bebas itu, yaitu dengan mendeteksi produk yang dihasilkan oleh reaksi radikal bebas, salah satunya berupa senyawa malondialdehid (MDA) (Niellsen, et all, 1997; Noguchi, Nikki, 1999).

Pada manusia, segera setelah dilakukan suatu aktivitas fisik aerobik dengan intensitas tinggi maka kadar MDA dalam plasma akan meningkat hingga tiga kali lipat di atas dari nilai normal pada saat istirahat (resting levels), selanjutnya pada jam ke-6 setelah aktivitas fisik kadar MDA akan mulai turun hingga kemudian pada akhirnya kadarnya akan kembali mencapai nilai resting levels pada jam ke24 setelah aktivitas fisik (McBride et al, 1998). Sedangkan pada mencit belum diketahui bagaimana proses peningkatan dan eliminasi kadar MDA bila dibandingkan dengan manusia. Belum diketahui berapa lama waktu yang dibutuhkan untuk mencapai kadar resting levels kembali setelah suatu aktivitas fisik yang menyebabkan peningkatan kadar MDA plasma. Oleh karena itu pada penelitian ini dilakukan pengambilan kadar MDA plasma mencit pada berbagai interval waktu setelah aktivitas fisik dengan treadmill pada menit ke-0, 15, 30, 60, dan 240 untuk melihat proses penurunan kadar MDA tersebut.

Agar eliminasi kadar MDA ini menjadi semakin cepat, maka dapat diberikan suatu suplemen antioksidan yang dapat berfungsi untuk mengurangi peningkatan kadar MDA sehingga selanjutnya akan mempercepat proses eliminasi MDA dari plasma. Dengan pemberian suplemen antioksidan tersebut, kadar MDA plasma yang meningkat setelah suatu aktivitas aerobik intensitas tinggi yang normalnya baru akan kembali ke nilai resting levels dalam 24 jam, dapat mencapai nilai resting levels tersebut hanya dalam 6 jam setelah aktivitas fisik (McBride, 1998).

Antioksidan dapat berasal dari sumber endogen maupun eksogen. Antioksidan endogen bekerja dengan cara mengikat gugus bebas dari oksidan sehingga akan mencegah kerusakan seluler. Kebanyakan antioksidan endogen bekerja secara enzimatik (Whitney, 2005). Untuk mencegah dampak negatif dari stres oksidatif yang diakibatkan oleh radikal bebas dibutuhkan antioksidan tambahan yang berasal dari luar (eksogen) untuk membantu kerja antioksidan endogen. Antioksidan eksogen yang dapat dikonsumsi sangat beragam, antara lain vitamin $C$, vitamin $E$, retinol (vitamin $A$ ), $\beta$-karoten, flavonoid dan lain sebagainya (Frei, 2003). Berbagai macam antioksidan tersebut terkandung dalam buah dan sayur diantaranya, vitamin $\mathrm{C}$ banyak terkandung pada jeruk Brastagi dan $\beta$ karoten yang banyak terkandung pada wortel.

Puluhan varietas jeruk ada di muka bumi. dari yang bercita rasa asam hingga manis. Walaupun berbeda warna, bentuk dan rasa, jeruk memiliki 
kesamaan, yaitu kaya akan antioksidan, tinggi mineral dan vitamin C.Jeruk Brastagi merupakan jeruk yang berasal dari wilayah Indonesia dan namanya sudah dikenal secara luas di nusantara. Jeruk Brastagi dikenal karena rasanya yang manis dan harganya yang ekonomis sehingga jeruk ini relatif banyak dikonsumsi oleh masyarakat. Meskipun masyarakat Indonesia banyak yang senang mengkonsumsi jeruk Brastagi, akan tetapi pemahaman dan pengetahuan mengenai manfaat jeruk Brastagi sebagai antioksidan belum diketahui secara merata.

Demikian pula halnya dengan wortel yang banyak mengandung $\beta$-karoten dan banyak ditanam di perkebunan di seluruh Indonesia. Pada umumnya wortel hanya dikonsumsi sebagai bahan sayuran atau minuman serta belum banyak dipahami berbagai manfaat lain dari wortel, salah satu contohnya adalah sebagai antioksidan. Wortel merupakan sumber utama $\beta$-karoten (Whitney dan Rolfes, 2005). $\beta$-karoten adalah karotenoid yang memiliki nilai vitamin A paling tinggi. $\beta$-karoten sebagai antioksidan berkerja dengan cara quenching active oxygen species dan radical-scavenging (Whitney dan Rolfes, 2005). $\beta$-karoten bersifat hidrofobik, sehingga memiliki efek langsung terhadap peroksidasi membran sel. $\beta$-karoten memiliki kemampuan untuk memecah singlet oksigen, yang lebih reaktif pada keadaan aerob dibandingkan dengan triplet oksigen (Shils, 2006). Reaksi karoten dengan radikal lipid menghasilkan molekul berinti karbon yang radikal. Pada proses selanjutnya molekul ini dapat menjadi prooksidan bila berada pada suasana aerob. Namun juga dapat bereaksi dengan lipid dan membentuk senyawa yang stabil. Sehingga pada tekanan oksigen yang rendah maka karoten berfungsi sebagai antioksidan (Papas, 1999).

Pembentukan radikal bebas pada suatu aktivitas fisik/olah raga aerobik diawali dengan terjadinya pelepasan satu elektron yang akan mengakibatkan terbentuknya suatu radikal bebas. Pemberian kombinasi vitamin $\mathrm{C}$ yang banyak terkandung dalam jeruk Brastagi dan $\beta$-karoten yang banyak terdapat pada wortel sebelum aktivitas fisik/olah raga aerobik dapat mengurangi peningkatan kadar MDA plasma dan mempercepat proses eliminasi MDA dari plasma. Pemberian antioksidan seperti vitamin $\mathrm{C}$, yang banyak terdapat pada jeruk, yang dikombinasi dengan $\beta$-karoten yang terkandung pada wortel dapat meningkatkan pertahanan terhadap stres oksidatif, dengan mencegah dan mengurangi terjadinya peroksidasi lipid, sehingga dapat mengurangi terjadinya pembentukan radikal bebas pada ekstrasel, membran dan intrasel yang pada akhirnya dapat menurunkan kadar MDA pada plasma (Ji, 1999; Clarkson dan
Thompson, 2000). Dengan pemberian kombinasi ekstrak jeruk Brastagi dan wortel, kadar MDA plasma mencit yang meningkat segera setelah suatu aktivitas fisik aerobik yang normalnya baru akan kembali ke nilai resting levels dalam 24 jam, akan dapat mencapai nilai resting levels tersebut dalam waktu yang lebih singkat. Kurangnya daya netralisasi terhadap radikal hidroksil dari vitamin $\mathrm{C}$ dikarenakan vitamin $\mathrm{C}$, yang bersifat hidrofilik, bereaksi dengan radikal hiroksil dengan kecepatan $10^{9} \mathrm{M}^{-1} \mathrm{~S}^{-1}$ sedangkan kecepatan reaksi radikal hidroksil dengan lemak sebesar $10^{8} \mathrm{M}^{-1} \mathrm{~S}^{-1}$ (Papas, 1999). Hal ini berarti radikal hidroksil lebih cepat bereaksi dengan lemak yang banyak terdapat pada membran sel dibandingkan dengan vitamin $C$ untuk menetralisasinya. Oleh karena lebih bersifat ekstra membran sel dan kurangnya daya netralisasi terhadap radikal hidroksil, maka kemungkinan vitamin $\mathrm{C}$ tidak sebaik anti oksidan larut lemak untuk mencegah peroksidasi lemak akibat radikal bebas (Shiels 2006, Papas, 1999). Oleh karena itu maka diperlukan kombinasi dari antioksidan eksogen lain yang larut lemak, seperti $\beta$-karoten yang banyak terkandung pada wortel, untuk menetralisasi radikal hidroksil yang terjadi sebagai hasil peroksidasi lemak pada membran sel yang kurang dapat dinetralisasi oleh vitamin C. Oleh karena $\beta$-karoten bersifat lipofilik maka antioksidan ini dapat bereaksi dengan kecepatan yang lebih tinggi dibanding vitamin $\mathrm{C}$ untuk menetralisasi radikal hidroksil yang terjadi akibat dari peroksidasi lipid pada membran sel sehingga peningkatan radikal bebas yang terbentuk dapat dicegah.

Hal yang menarik adalah sampai saat ini masyarakat pada umumnya belum mengetahui dengan jelas bagaimana pengaruh pemberian kombinasi ekstrak jeruk Brastagi dan wortel terhadap perubahan kadar MDA yang terbentuk pada saat aktivitas fisik aerobik dengan intensitas tinggi serta seberapa besar pengaruh pemberian kombinasi kedua ekstrak tersebut terhadap proses eliminasi kadar MDA plasma. Oleh karena itu untuk tahap penelitian awal, dilakukan penelitian pada mencit. Mencit (Mus muculus) memiliki mekanisme fisiologis tubuh yang menyerupai manusia, yang berfungsi untuk mencegah kerusakan tubuh terhadap timbulnya oksidan yang berlebihan (Whitney, 2005). Untuk mencegah dampak negatif dari stres oksidatif radikal bebas pada mencit dibutuhkan antioksidan tambahan yang berasal dari luar (eksogen) untuk membantu kerja antioksidan endogen. Pada penelitian awal ini kelompok mencit diberi kombinasi ekstrak jeruk Brastagi dan wortel sebelum melakukan aktivitas fisik aerobik dengan menggunakan treadmill mencit selama 20 menit dengan kecepatan 1,25 m/detik, kemudian diukur 
kadar MDA nya pada menit ke-0, 15, 30, 60, dan 240. Hasil perubahan kadar MDA yang didapatkan akan dibandingkan dengan kelompok mencit yang tidak diberi kombinasi ekstrak jeruk Brastagi dan wortel sebelum aktivitas fisik. Dengan demikian dapat diketahui bagaimana pengaruh pemberian kombinasi ekstrak jeruk Brastagi dan wortel sebelum aktivitas fisik terhadap penurunan kadar MDA mencit. Diharakan hasil dari penelitian ini pada akhirnya akan dapat diaplikasikan kepada manusia.

Berdasarkan uraian diatas maka dilakukanlah penelitian mengenaipengaruh pemberian kombinasi ekstrak jeruk Brastagi dan wortel sebelum aktivitas fisik terhadap penurunan kadar MDA mencit yang diukur setelah aktivitas fisik.

\section{METODE}

Objek penelitian berupa mencit (Mus musculus) putih jantan dari galur Swibsibter umur 6-8 minggu dengan berat badan 25-30 gram yang dipilih secara acak. Jumlah sampel penelitian sebanyak 40 ekor mencit yang kemudian dibagi menjadi 2 kelompok (A dan B) dengan masingmasing kelompok terdiri dari 20 ekor mencit. Setiap kelompok dibagi lagi menjadi 5 kelompok $(1,2,3,4,5)$ dengan jumlah tiap-tiap kelompok adalah 4 ekor mencit. Hewan penelitian diberi makan campuran pelet dan gabah dan diberi minum secukupnya selama penelitian.

Penentuan jumlah sampel tiap kelompok didasarkan pada formulasi Federrer. Banyaknya perlakuan adalah 10 , sehingga jumlah sampel tiap kelompok :

$$
\begin{aligned}
& (\mathrm{r}-1)(\mathrm{t}-1) \geq 15 \\
& (\mathrm{r}-1)(10-1) \geq 15 \\
& (\mathrm{r}-1) 9 \geq 15 \\
& (\mathrm{r}-1) \geq 15 / 9 \\
& \mathrm{r} \geq 2,7
\end{aligned}
$$

Kriteria inklusi pada penelitian ini adalah :

1. Mencit (Mus musculus) putih jantan galur Swibsibter

2. Berumur 6-8 minggu

3. Berat badan rata-rata 25-30 gram

4. Didapatkan dari tempat pembiakan yang

sama, pakan yang sama.

Tipe penelitian adalah studi eksperimental laboratorium dalam bidang Ilmu Faal dan Kedokteran Olahraga yang dilanjutkan dengan pemeriksaan darah. Eksperimen dilakukan di laboratorium Unit Penelitian Kesehatan RSHS Bandung. Variabel penelitian ini terdiri variabel perlakuan (independent) dan variabel respon (dependent).

1. Variabel perlakuan adalah kombinasi ekstrak jeruk Brastagi dan wortel.
2. Variabel respon penelitian ini adalah

kadar MDA plasma mencit pada menit ke- 0,15 , 30, 60, dan 240 .

Untuk menjelaskan variabel-variabel yang terlibat dalam penelitian ini maka diberikan definisi secara operasional sesuai konteks penelitian

\section{Aktivitas Fisik}

Mencit diberi perlakuan dengan aktivitas fisik menggunakan treadmill mencit yang digerakkan dengan elektroda selama 20 menit dengan kecepatan $1,25 \mathrm{~m} / \mathrm{s}$ tanpa henti.

2. Ekstrak Jeruk Brastagi

Ekstraksi dari jeruk Brastagi dengan membandingkan komposisi kadar vitamin $\mathrm{C}$ per sampel (49 mg/100 gr jeruk).

3. Ekstrak Wortel

Ekstraksi dari wortel dengan perhitungan kadar $\beta$-karoten per sampel. Kandungan wortel diperhitungkan memiliki kadar vitamin A yang tinggi yaitu sebesar 12.000 SI.

Kelompok A adalah kelompok mencit sebanyak 20 ekor yang diambil secara acak dan kemudian diberi kombinasi ekstrak jeruk Brastagi dan wortel sebelum aktivitas fisik dengan treadmill mencit selama 20 menit, dengan kecepatan 1,25 m/detk.. Kelompok A dibagi menjadi 5 kelompok, yaitu :

Kelompok 1 : diberi kombinasi ekstrak jeruk Brastagi dan wortel sebelum aktivitas fisik menggunakan treadmill mencit selama 20 menit dengan kecepatan $1,25 \mathrm{~m} / \mathrm{s}$ tanpa henti, dan kemudian dimatikan untuk diambil sampel darah untuk pemeriksaan MDA plasma pada menit ke0 sebanyak 4 ekor

Kelompok 2 : diberi kombinasi ekstrak jeruk Brastagi dan wortel sebelum aktivitas fisik menggunakan treadmill mencit selama 20 menit dengan kecepatan $1,25 \mathrm{~m} / \mathrm{s}$ tanpa henti, dan kemudian dimatikan untuk diambil sampel darah untuk pemeriksaan MDA plasma pada menit ke15 sebanyak 4 ekor

Kelompok 3 : diberi kombinasi ekstrak jeruk Brastagi dan wortel sebelum aktivitas fisik menggunakan treadmill mencit selama 20 menit dengan kecepatan $1,25 \mathrm{~m} / \mathrm{s}$ tanpa henti, dan kemudian dimatikan untuk diambil sampel darah untuk pemeriksaan MDA plasma pada menit ke30 sebanyak 4 ekor

Kelompok 4 : diberi kombinasi ekstrak jeruk Brastagi dan wortel sebelum aktivitas fisik menggunakan treadmill mencit selama 20 menit dengan kecepatan $1,25 \mathrm{~m} / \mathrm{s}$ tanpa henti, dan kemudian dimatikan untuk diambil sampel darah untuk pemeriksaan MDA plasma pada menit ke60 sebanyak 4 ekor

Kelompok 5 : diberi kombinasi ekstrak jeruk 
Brastagi dan wortel sebelum aktivitas fisik menggunakan treadmill mencit selama 20 menit dengan kecepatan $1,25 \mathrm{~m} / \mathrm{s}$ tanpa henti, dan kemudian dimatikan untuk diambil sampel darah untuk pemeriksaan MDA pasma pada menit ke240 sebanyak 4 ekor.

Kelompok B adalah kelompok mencit sebanyak 20 ekor yang diambil secara acak dan tidak diberi kombinasi ekstrak jeruk Brastagi dan wortel sebelum aktivitas fisik menggunakan treadmill mencit selama 20 menit dengan kecepatan 1,25 m/s tanpa henti. Kelompok B dibagi menjadi 5 kelompok, yaitu :

Kelompok 1 : tidak diberi kombinasi ekstrak jeruk Brastagi dan wortel sebelum aktivitas fisik menggunakan treadmill mencit selama 20 menit dengan kecepatan $1,25 \mathrm{~m} / \mathrm{s}$ tanpa henti, kemudian dimatikan untuk diambil sampel darah untuk pemeriksaan MDA plasma pada menit ke-0 sebanyak 4 ekor.

kelompok 2 : tidak diberi kombinasi ekstrak jeruk Brastagi dan wortel sebelum aktivitas fisik menggunakan treadmill mencit selama 20 menit dengan kecepatan $1,25 \mathrm{~m} / \mathrm{s}$ tanpa henti, kemudian dimatikan untuk diambil sampel darah untuk pemeriksaan MDA plasma pada menit ke-15 sebanyak 4 ekor.

kelompok 3 : tidak diberi kombinasi ekstrak jeruk Brastagi dan wortel sebelum aktivitas fisik menggunakan treadmill mencit selama 20 menit dengan kecepatan $1,25 \mathrm{~m} / \mathrm{s}$ tanpa henti, kemudian dimatikan untuk diambil sampel darah untuk pemeriksaan MDA plasma pada menit ke-30 sebanyak 4 ekor.

kelompok 4 : tidak diberi kombinasi ekstrak jeruk Brastagi dan wortel sebelum aktivitas fisik menggunakan treadmill mencit selama 20 menit dengan kecepatan $1,25 \mathrm{~m} / \mathrm{s}$ tanpa henti, kemudian dimatikan untuk diambil sampel darah untuk pemeriksaan MDA plasma pada menit ke-60 sebanyak 4 ekor.

kelompok 5 : tidak diberi kombinasi ekstrak jeruk Brastagi dan wortel sebelum aktivitas fisik menggunakan treadmill mencit selama 20 menit dengan kecepatan $1,25 \mathrm{~m} / \mathrm{s}$ tanpa henti, kemudian dimatikan untuk diambil sampel darah untuk pemeriksaan MDA plasma pada menit ke-240 sebanyak 4 ekor.

6. MDA

Adalah senyawa yang dapat digunakan sebagai indikator radikal bebas yang dihasilkan akibat reaksi peroksidasi lemak yang terdapat pada membran sel. Pemeriksaan dilakukan dengan biopsi hati atau mengambil darah jantung sehingga mencit hanya dapat digunakan untuk satu kali pemeriksaan.

Analisis data penelitian diproses dengan program SPSS V. 13.0 for windows dengan, langkah-langkahnya sebagai berikut:

Data yang diperoleh melalui hasil pengukuran kemudian dilakukan uji

1. Homogenitas data dengan uji Levene $(\mathrm{p}>0,05)$

2. Normalitas dengan uji KolmogorovSmirnor $(p>0,05$

3. Jika data berdistribusi normal dan homogen maka untuk menguji

perbedaan antara kedua kelompok, analisis dilanjutkan dengan uji t tidak berpasangan $(\mathrm{p}<0,05)$.

\section{HASIL dan PEMBAHASAN}

\section{Karakteristik Fisik Fisiologis Objek Penelitian}

Rata-rata dan standar deviasi karakteristik fisik fisiologis objek penelitian berupa berat badan (gram) dan kadar MDA (nmol/ml) dalam berbagai pengukuran terdapat pada tabel 1 .

Tabel 1Karakteristik Fisik Fisiologis Objek Penelitian

\begin{tabular}{|c|c|c|c|}
\hline Berat Badan dan Kadar MDA & $\mathbf{x}$ & \pm & $\mathbf{S}$ \\
\hline Berat badan (gr) & 27,48 & \pm & 1,19 \\
\hline A1 : Kadar MDA dgn ekstrak diukur stlh 0 mnt (nmol/ml) & 0,8920 & \pm & 0,0295 \\
\hline A2 : Kadar MDA dgn ekstrak diukur stlh $15 \mathrm{mnt}(\mathrm{nmol} / \mathrm{ml})$ & 0,7902 & \pm & 0,0354 \\
\hline A3 : Kadar MDA dgn ekstrak diukur stlh $30 \mathrm{mnt}(\mathrm{nmol} / \mathrm{ml})$ & 0,7473 & \pm & 0,0663 \\
\hline A4 : Kadar MDA dgn ekstrak diukur stlh $60 \mathrm{mnt}(\mathrm{nmol} / \mathrm{ml})$ & 0,6696 & \pm & 0,0333 \\
\hline A5 : Kadar MDA dgn ekstrak diukur stlh $240 \mathrm{mnt}(\mathrm{nmol} / \mathrm{ml})$ & 0,5786 & \pm & 0,0455 \\
\hline B1 : Kadar MDA tanpa ekstrak diukur stlh $0 \mathrm{mnt}(\mathrm{nmol} / \mathrm{ml})$ & 1,0071 & \pm & 0,0446 \\
\hline B2 : Kadar MDA tanpa ekstrak diukur stlh $15 \mathrm{mnt}(\mathrm{nmol} / \mathrm{ml})$ & 0,9348 & \pm & 0,0633 \\
\hline B3 : Kadar MDA tanpa ekstrak diukur stlh $30 \mathrm{mnt}(\mathrm{nmol} / \mathrm{ml})$ & 0,8732 & \pm & 0,0529 \\
\hline B4 : Kadar MDA tanpa ekstrak diukur stlh $60 \mathrm{mnt}(\mathrm{nmol} / \mathrm{ml})$ & 0,7554 & \pm & 0,0333 \\
\hline B5 : Kadar MDA tanpa ekstrak diukur stlh $240 \mathrm{mnt}(\mathrm{nmol} / \mathrm{ml})$ & 0,6696 & \pm & 0,0514 \\
\hline Kontrol : Kadar MDA tanpa ekstrak, tanpa aktivitas fisik (nmol/ml) & 0,7554 & \pm & 0,1070 \\
\hline
\end{tabular}

Keterangan : MDA $=$ Malondialdehid; $\mathrm{x}=$ Rata-rata; $\mathrm{s}=$ Standar Deviasi 
Tabel 2Hasil Pengujian Normalitas PengukuranKadar MDA Plasma Mencit yangDiukur pada Menit ke-0, $15,30,60,240$

\begin{tabular}{lcc}
\hline \multicolumn{1}{c}{ Perlakuan } & $\mathbf{Z}$ & nilai-p \\
\hline A1 : Aktifitas fisik dengan ekstrak diukur stlh 0 menit & 0,475 & 0,978 \\
A2 : Aktifitas fisik dengan ekstrak diukur setelah 15 menit & 0,439 & 0,991 \\
A3 : Aktifitas fisik dengan ekstrak diukur setelah 30 menit & 0,596 & 0,869 \\
A4 : Aktifitas fisik dengan ekstrak diukur setelah 60 menit & 0,628 & 0,825 \\
A5 : Aktifitas fisik dengan ekstrak diukur setelah 240 menit & 0,521 & 0,949 \\
B1 : Aktifitas fisik tanpa ekstrak diukur setelah 0 menit & 0,310 & 1,000 \\
B2 : Aktifitas fisik tanpa ekstrak diukur setelah 15 menit & 0,797 & 0,549 \\
B3 : Aktifitas fisik tanpa ekstrak diukur setelah 30 menit & 0,388 & 0,998 \\
B4 : Aktifitas fisik tanpa ekstrak diukur setelah 60 menit & 0,628 & 0,825 \\
B5 : Aktifitas fisik tanpa ekstrak diukur setelah 240 menit & 0,535 & 0,937 \\
Kontrol & 0,619 & 0,838 \\
\hline Z & &
\end{tabular}

$\mathrm{Z}=$ uji normalitas $(\mathrm{p}>0,05)$ data berdistribusi normal

\section{Uji Homogenitas dan Uji Normalitas Data}

Dari rata-rata dan simpangan baku kadar MDA plasma pada berbagai pengukuran yang terdapat pada tabel 1 dilakukankan uji normalitas Kolmogorov-Smirnov ( $p>0,05)$ dan uji homogenitas varians Levene test $(\mathrm{p}>0,05)$. Hasilnya menunjukkan data berdistribusi normal dan memiliki varians yang relatif homogen seperti yang tertera pada tabel 2 dan 3.

Tabel 3Hasil Pengujian Homogenitas Pengukuran Kadar MDA Plasma Mencit yang Diukur pada Menit ke$0,15,30,60,240$

\begin{tabular}{lccccccccccc}
\hline \multirow{2}{*}{ Perlakuan } & \multicolumn{2}{c}{$\mathbf{0}$ menit } & \multicolumn{2}{c}{$\mathbf{1 5}$ menit } & \multicolumn{2}{c}{$\mathbf{3 0}$ menit } & \multicolumn{6}{c}{$\mathbf{6 0}$ menit } & \multicolumn{2}{c}{$\mathbf{2 4 0}$ menit } \\
\cline { 2 - 10 } & $\begin{array}{c}\text { Levene's } \\
\text { test } \mathbf{F}\end{array}$ & $\begin{array}{c}\text { Nilai- } \\
\mathbf{p}\end{array}$ & $\begin{array}{c}\text { Levene's } \\
\text { test } \mathbf{F}\end{array}$ & $\begin{array}{c}\text { Nilai- } \\
\mathbf{p}\end{array}$ & $\begin{array}{c}\text { Levene's } \\
\text { test } \mathbf{F}\end{array}$ & $\begin{array}{c}\text { Nilai- } \\
\mathbf{p}\end{array}$ & $\begin{array}{c}\text { Levene's } \\
\text { test } \mathbf{F}\end{array}$ & $\begin{array}{c}\text { Nilai- } \\
\mathbf{p}\end{array}$ & $\begin{array}{c}\text { Levene's } \\
\text { test } \mathbf{F}\end{array}$ & Nilai-p \\
\hline $\begin{array}{l}\text { Dengan } \\
\text { ekstrak (A) } \\
\begin{array}{l}\text { Tanpa } \\
\text { ekstrak (B) }\end{array}\end{array}$ & 0,367 & 0,567 & 1,332 & 0,292 & 0,003 & 0,956 & 0,000 & 1,000 & 0,302 & 0,602 \\
\hline
\end{tabular}

Keterangan : $p$ uji homogenitas $(p>0,05)$ data homogen

Perbedaan Kadar Malondialdehid (MDA) Plasma Mencit yang Diukur pada Menit ke-0 Setelah Aktivitas Fisik pada Mencit yang Diberi dan Tidak Diberi Kombinasi Ekstrak Jeruk Brastagidan Wortel

Rata-rata dan standar deviasi kadar MDA plasma yang diukur pada menit ke-0 setelah aktivitas fisik pada mencit yang diberi dan yang tidak diberi kombinasi ekstrak jeruk Brastagi dan wortel terdapat pada tabel 1. Selanjutnya dilakukan uji $t$ independen $(\mathrm{p}<0,05)$ untuk mengetahui perbedaan kadar MDA plasma pada menit ke-0 setelah aktivitas fisik pada mencit yang diberi dan tidak diberi kombinasi ekstrak jeruk Brastagi dan wortel. Hasilnya, kadar MDA plasma yang diukur pada kelompok mencit yang diberi kombinasi ekstrak jeruk Brastagi dan wortel lebih rendah bila dibandingkan dengan kelompok mencit yang tidak diberi kombinasi ekstrak tersebut, seperti tercantum pada tabel 4 . 
Tabel 4Uji t Independen Perbedaan Kadar MDA Plasma Mencit yang Diukur pada Menit Ke-0 Setelah Aktivitas Fisik Antara Kelompok Mencit yang Diberi dengan yang Tidak Diberi Kombinasi Ekstrak Jeruk Brastagi dan Wortel Sebelum Aktivitas Fisik

\begin{tabular}{lcccccc}
\hline \multicolumn{1}{c}{ Perlakuan } & $\mathbf{x}$ & \pm & $\mathbf{s}$ & $\begin{array}{c}\text { statistik } \\
\text { uji t }\end{array}$ & nilai-p & Keterangan \\
\hline $\begin{array}{l}\text { A1 : Aktivitas fisik dengan ekstrak } \\
\text { diukur setelah 0 menit }\end{array}$ & 0,8920 & \pm & 0,0295 & & & \\
& & & & $-4,309$ & $0,005^{* *}$ & $\begin{array}{c}\text { Sangat } \\
\text { signifikan }\end{array}$ \\
$\begin{array}{l}\text { B1 : Aktifitas fisik tanpa ekstrak } \\
\text { diukur setelah 0 menit }\end{array}$ & 1,0071 & \pm & 0,0446 & & & \\
\hline
\end{tabular}

Keterangan : * = signifikan (bermakna) pada taraf kekeliruan $5 \%(\mathrm{p} \leq 0,05)$

$* *=$ sangat signifikan (bermakna) pada taraf kekeliruan $1 \%(\mathrm{p} \leq 0,01)$

Perbedaan Kadar Malondialdehid (MDA) Plasma Mencit yang Diukur pada Menit Ke-15 Setelah Aktivitas Fisik pada Mencit yang Diberi dan yang Tidak Diberi Kombinasi Ekstrak Jeruk Brastagidan Wortel Sebelum Aktivitas Fisik

Rata-rata dan standar deviasi kadar MDA plasma yang diukur pada menit ke-15 setelah aktivitas fisik pada mencit yang diberi dan tidak diberi kombinasi ekstrak jeruk Brastagi dan wortel sebelum aktivitas fisik terdapat pada tabel1. Selanjutnya dilakukan uji $\mathrm{t}$ independen $(\mathrm{p}<0,05)$ untuk mengetahui perbedaan kadar MDA plasma pada menit ke-15 setelah aktivitas fisik pada mencit yang diberi dan tidak diberi kombinasi ekstrak jeruk Brastagi dan wortel sebelum aktivitas fisik. Hasilnya, kadar MDA plasma yang diukur pada kelompok mencit yang diberi kombinasi ekstrak jeruk Brastagi dan wortel sebelum aktivitas fisik lebih rendah dibandingkan dengan kelompok mencit yang tidak diberi kombinasi ekstrak tersebut, seperti tercantum pada tabel 5 .

Tabel 5Uji t Independen Perbedaan Kadar Malondialdehide (MDA) Plasma Mencit yang Diukur pada Menit ke-15 Setelah Aktivitas Fisik Antara Mencit Yang Sebelumnya Diberi Dengan yang Tidak Diberi Kombinasi Ekstrak Jeruk Brastagi dan Wortel

\begin{tabular}{lccccccc}
\multicolumn{1}{c}{ Perlakuan } & $\mathbf{X}$ & \pm & $\mathbf{s}$ & $\begin{array}{c}\text { statistik } \\
\text { uji t }\end{array}$ & nilai-p & Keterangan \\
\hline $\begin{array}{l}\text { A2 : Aktifitas fisik dengan ekstrak } \\
\text { diukur setelah 15 menit }\end{array}$ & 0,7902 & \pm & 0,0354 & & & \\
$\begin{array}{l}\text { B2: Aktifitas fisik tanpa ekstrak } \\
\text { diukur setelah 15 menit }\end{array}$ & 0,9348 & \pm & 0,0633 & $-3,988$ & $0,007^{* *}$ & $\begin{array}{c}\text { Sangat } \\
\text { signifikan }\end{array}$ \\
\hline
\end{tabular}

Keterangan : * = signifikan (bermakna) pada taraf kekeliruan $5 \%(\mathrm{p} \leq 0,05)$

$* *=$ sangat signifikan (bermakna) pada taraf kekeliruan $1 \%(\mathrm{p} \leq 0,01)$

Perbedaan Kadar Malondialdehid (MDA) Plasma Mencit yang Diukur pada Menit Ke-30 Setelah Aktivitas Fisik pada Mencit yang Diberi dan Tidak Diberi Kombinasi Ekstrak Jeruk Brastagidan Wortel Sebelum Aktivitas Fisik

Rata-rata dan standar deviasi kadar MDA plasma yang diukur pada menit ke-30 setelah aktivitas fisik pada mencit yang diberi dan tidak diberi kombinasi ekstrak jeruk Brastagi dan wortel sebelum aktivitas fisik terdapat pada tabel 1 . Selanjutnya dilakukan uji $\mathrm{t}$ independen $(\mathrm{p}<0,05)$ untuk mengetahui perbedaan kadar MDA plasma pada menit ke-30 setelah aktivitas fisik pada mencit yang diberi dan tidak diberi kombinasi ekstrak jeruk Brastagi dan wortel sebelum aktivitas fisik. Hasilnya, kadar MDA plasma yang diukur pada kelompok mencit yang diberi kombinasi ekstrak jeruk Brastagi dan wortel sebelum aktivitas fisik lebih rendah dibandingkan dengan kelompok mencit yang tidak diberi kombinasi ekstrak tersebut, seperti tercantum pada tabel 6 . 
Tabel 6 Uji t Independen Perbedaan Kadar Malondialdehide (MDA) Plasma Mencit Yang Diukur Pada Menit Ke-30 Setelah Aktivitas Fisik Antara Mencit Yang Sebelumnya Diberi Dengan Yang Tidak Diberi Kombinasi Ekstrak Jeruk Brastagi dan Wortel

$\begin{array}{lllllll}\text { Perlakuan } & X & \pm & \text { s } & \begin{array}{c}\text { statistik } \\ \text { uji } t\end{array} & \text { nilai-p } & \text { Keterangan }\end{array}$

\begin{tabular}{lcccccc}
\hline $\begin{array}{l}\text { A3 : Aktifitas fisik dengan ekstrak } \\
\text { diukur setelah } 30 \text { menit }\end{array}$ & $0,7473 \quad \pm 0,0663$ & & & \\
$\begin{array}{l}\text { B3 : Aktifitas fisik tanpa ekstrak } \\
\text { diukur setelah 30 menit }\end{array}$ & $0,8732 \quad \pm \quad 0,0529$ & & & Signifikan \\
\hline
\end{tabular}

Keterangan : * = signifikan (bermakna) pada taraf kekeliruan $5 \%(\mathrm{p} \leq 0,05)$

$* *$ = sangat signifikan (bermakna) pada taraf kekeliruan $1 \%(\mathrm{p} \leq 0,01)$

Perbedaan Kadar Malondialdehid (MDA) Plasma Mencit yang Diukur pada Menit ke-60 Setelah Aktivitas Fisik pada Mencit yang Diberi dan Tidak Diberi Kombinasi Ekstrak Jeruk Brastagidan Wortel Sebelum Aktivitas Fisik

Rata-rata dan standar deviasi kadar MDA plasma yang diukur pada menit ke-60 setelah aktivitas fisik pada mencit yang diberi dan tidak diberi kombinasi ekstrak jeruk Brastagi dan wortel sebelum aktivitas fisik terdapat pada tabel 1 . Selanjutnya dilakukan uji $\mathrm{t}$ independen $(\mathrm{p}<0,05)$ untuk mengetahui perbedaan kadar MDA plasma pada menit ke-60 setelah aktivitas fisik pada mencit yang diberi dan tidak diberi kombinasi ekstrak jeruk Brastagi dan wortel sebelum aktivitas fisik. Hasilnya, kadar MDA plasma yang diukur pada kelompok mencit yang diberi kombinasi ekstrak jeruk Brastagi dan wortel sebelum aktivitas fisik lebih rendah dibandingkan dengan kelompok mencit yang tidak diberi kombinasi ekstrak tersebut, seperti tercantum pada tabel 7.

Tabel 7Uji t Independen Perbedaan Kadar Malondialdehide (MDA) Plasma Mencit Yang Diukur Pada Menit ke-60 Setelah Aktivitas Fisik Antara Mencit Yang Sebelumnya Diberi Dengan yang Tidak Diberi Kombinasi Ekstrak Jeruk Brastagi dan Wortel

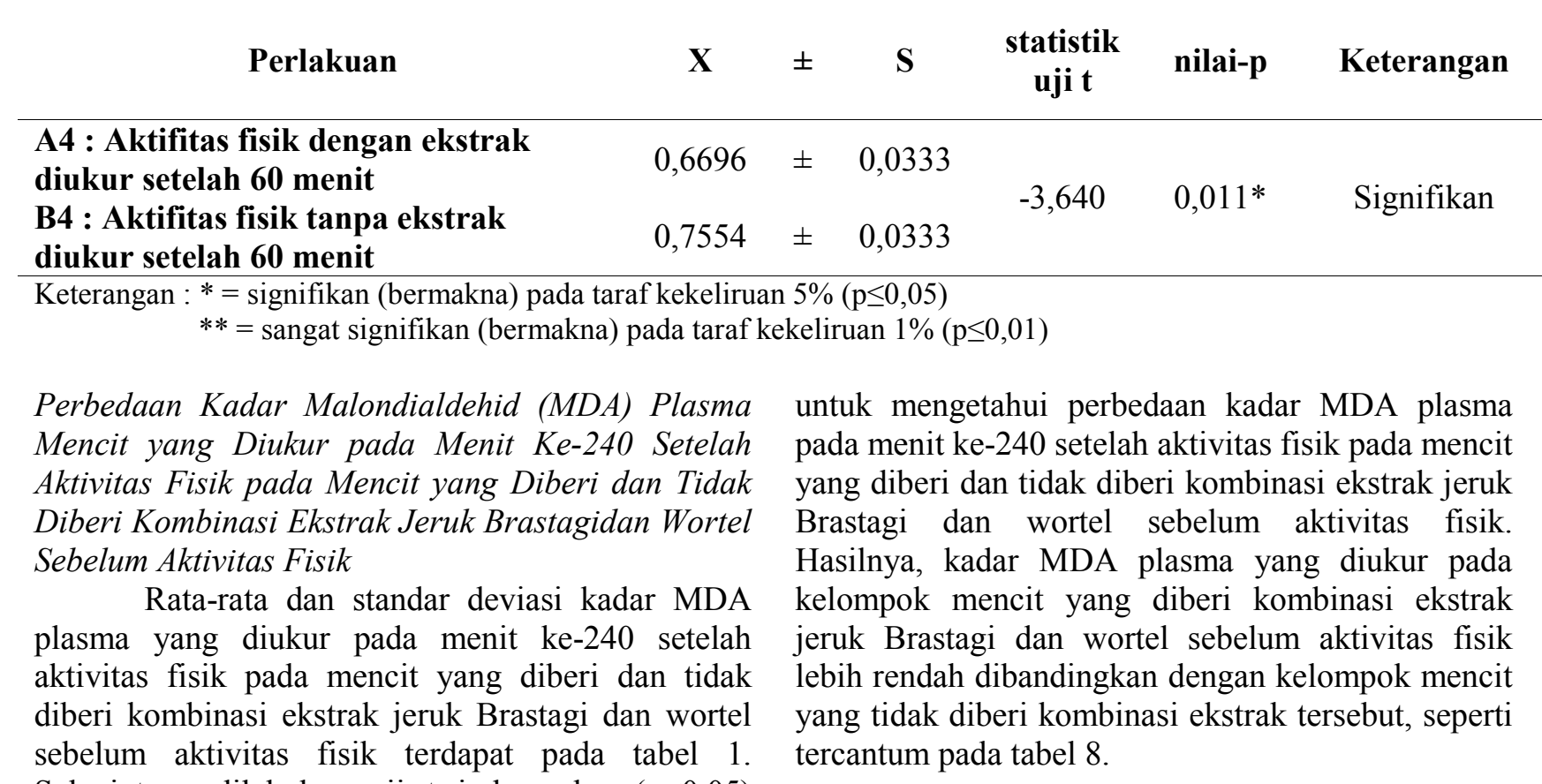

Selanjutnya dilakukan uji $\mathrm{t}$ independen $(\mathrm{p}<0,05)$ 
Tabel 8 Uji t Independen Perbedaan Kadar Malondialdehide (MDA) Plasma Mencit yang Diukur pada Menit ke-240 Setelah Aktivitas Fisik Antara Mencit yang Sebelumnya Diberi Dengan yang Tidak Diberi Kombinasi Ekstrak Jeruk Brastagi dan Wortel

\begin{tabular}{lcccccc}
\hline \multicolumn{1}{c}{ Perlakuan } & $\mathbf{X}$ & \pm & $\mathbf{s}$ & $\begin{array}{c}\text { statistik } \\
\text { uji t }\end{array}$ & nilai-p & Keterangan \\
\hline $\begin{array}{l}\text { A5 : Aktifitas fisik dengan ekstrak } \\
\text { diukur setelah 240 menit }\end{array}$ & 0,5786 & \pm & 0,0455 & & & \\
$\begin{array}{l}\text { B5 : Aktifitas fisik tanpa ekstrak } \\
\text { diukur setelah 240 menit }\end{array}$ & 0,6696 & \pm & 0,0514 & $-2,654$ & $0,038^{*}$ & Signifikan \\
\hline
\end{tabular}

Keterangan : * = signifikan (bermakna) pada taraf kekeliruan 5\% $(\mathrm{p} \leq 0,05)$

$* *$ = sangat signifikan (bermakna) pada taraf kekeliruan $1 \%(\mathrm{p} \leq 0,01)$

\section{KESIMPULAN}

Berdasarkan hasil penelitian yang telah dilakukan, maka diambil kesimpulan sebagai berikut: Pemberian kombinasi ekstrak jeruk Brastagi dan wortel sebelum aktivitas fisik menyebabkan kadar
MDA plasma mencit yang diukur pada berbagai interval waktu pasca aktivitas fisik lebih rendah bila dibandingkan dengan kelompok yang tidak diberi ekstrak.

\section{DAFTAR PUSTAKA}

1. Ames, B., Shigenaga, M. K., Hagen, T. 1993. Oxidants, Antioxidants, and Degenerative Diseases of Aging. Proc Natl Acd Sci (90):7915-22.

2. Astrand, P.O., Rodahl, K. 1986. Textbook of Work Physiology, Physiological Bases of Exercises. Mc Graw. Hill Book Company. New York. 3th ed: $293-$ 348, 501-512, 523-576, 684.

3. Atalay, N. 2007. Effect of Different Resistance Exercise Protocols on Nitric Oxide, Lipid Peroxidation and Creatine Kinase Activity in Sedentary Males. Ankara

4. Berner, Y. N. 2006. Nutrition and aging. Turkish J of Geriatr, 2:097-107.

5. Best, Thomas, M., Fiebig, M., Corr, David, T., Brickson, Stacey, Ji, L., Li. 1999. Free Radical Activity, Antioxidant Enzyme and Gluthathione Changes with Muscle Stretch Injury in Rabbits. $J$ Appl Physiol. 87(1):74-82.

6. Block, G., Norkus, E., Hudes, M., Mandel, S., Helzlsouer, K. 2001. Which Plasma Antioxidants Are Most Related to Fruit and Vegetable Consumption?. American J of Epid, 154(12): 1113-1118.

7. Booron, WF., Boulpep, EL. 2003. Medical Physiology. Philadelphia; Elsevier Saunders.

8. Brooks, A. And Fahey, D. 1985. Exercise Physiology. Human Bioenergetics and Sts Applications. Mc Millan Publishing Company. New York; 701-722

9. Campbell, N.A.,etc. 2000. Third ed., Biology; Concept and Connections. Benjamin Cummings, An imprint of Addison Wesley Longman, Inc.

10. Carr, A.C. and Frei, B. 1999. Toward A New Recommended Dietary Allowance for Vitamin C based on Antioxidant and Health Effects in Humans. American J of Clin Nutr. 69; 1086-107.

11. Carre, F.A., Corbin, C. B., Lindsey, R. 1980. Physical Education Concepts: Fitness for Life. Sage Publising Limited. Canada.
12. Chappell, M.,et al. 2004. Voluntary running in deer mice: speed, distance, energy costs and temperature effects. J of Experiment Biol. 207:3839-3854.

13. Chen, Q., Espey, M.G., Sun, A.Y., et al. 2007. Ascorbate in Pharmacologic Concentrations Selectively Generates Ascorbate Radical and Hydrogen Peroxide in Extracellular Fluid in Vivo. National Institutes of Health, Bethesda MD.

14. Clarkson, P. M., Thompson, H. S. 2000. Antioxidant: What Role do They Play in Physical Activity and Health. The American J of Clin Nutr, vol. 72, no. 2, 637S-646s.

15. Collins, A. 2005. Assays for Oxidative Stress and Antioxidant Status: Applications to Research into the Biological Effectiveness of Polyphenols. American J of Clin Nutr. 81(1):261S-267S.

16. Congy, F., Bonnefont-Rousselot, D., Dever S., et al. 1995. Study of Oxidative Stress in the Elderly. Europe PMC. 24:1115-1118.

17. Cross, CE, Valacchi, G., Schock, B., Wilson, M., Weber, S., Eiserich, J and Van der Vliet A. 2002. Environmental Oxidant Pollutant Effects on Biologic Systems, a Focus on Micronutrient AntioxidantOxidant Interactions. American Journal of Respiratory and Critical Care Medicine Vol 166. pp. S44-S50.

18. Ctler, R.G., Rodriguez, H., 2003. Critical Reviews of Oxidative Stress and Aging, Advances in Basic Science, Diagnostics and Intervention. New Jersey: World Scientific.

19. Ditjen, BP Hortikultura, Direktorat Tanaman Buah, Vademekum Jeruk. 2002. Daftar Kandungan Gizi dalam 100 gram Jeruk. Melalui <http://www.citrusindonesia.com/>. [20/01/08]

20. Droge, W. 2002. Free Radicals in the Physiological Control of Cell Function. American Physiol Soci. Physiol. Rev. 82: 47-95

21. Evans, W.J. 2000. Vitamin E, vitamin C, and Exercise. American Journal of Clin Nutr, 72(2): 647S-652S. 
22. Finkel, T. 2003. Oxidant Signals and Oxidative Stress I (review). Curr Opin Cell Biol; 15; 247-54

23. Finkel, T. Hoolbrook, NJ. 2004. Oxidants, Oxidative Stress and The Biology of Aging (review). Nature; 408; 239-47

24. Foss, M. L., Keteyian, S.J. 1998. Foxs Physiological Basic for Excercise and Sport $6^{\text {th }}$ edition. USA: Mcgraw Hill Company.

25. Fox, L. 1979. Sports Physiology. Philadelphia: W.B. Saunders Company, p:27\&34.

26. Fox, L.E, Bower, W.R; Foss, M.L, 1988. The Physiological Basic of Physical Education. Fourth Edition, Saunders College Publishing: 166.

27. Frei, B. 2003. To C or Not to C, That is the Question!. J of American Col of Cardiol. 42 (2): 246255.

28. Fukutomi, Takayama, Akashi, Tanaka, S. Nanasawa, T., Matsuo, K. Et al. 2001. Multicentricity and histopathological Features of Familial Breas Cancers Stratified by Menopausal Status. Int. J. Clin Oncol; 6; $80-83$.

29. Ganong, W. 1983. Review of Medical Physiology, $11^{\text {th }}$ Ed.. Lange Medical Publications. Los Altos. California.: 25; 52-53; 225-232; 580-582; 591-596.

30. Giam, C.K., Teh, K.C. 1993. Sport Medicine: Exercise and Fitnes. PG Publising Pte Ltd. Singapore.

31. Guyton, A. 2000. Text Book of Medical Phyisology. Philadelphia: W.B.Saunders. 10th ed.; 133, 438-451, 808-817, 1010-1014.

32. Haliwell, B. 2001. Role of Free Radicals in Neurodegenerative Disease, Therapeutic Implications for Antioxidant treatment (Review); Drugs \& Aging. 18: 685-716.

33. Haliwell, B., Gutteridge. 1998. Free Radical in Biology and Medicine 2nd Ed. New York: Oxford University Press.

34. Haliwell, B., Whiteman M. 2004. Measuring rective specie and oxidative damage in vivo and in cell culture; how should you do it and the results mean (Review). Br. J. Pharmacol; 142; 31-55.

35. Halvorsen, B.L., et al. 2006. Content of redox-active compounds (ie, antioxidants) in foods consumed in the United States. American J of Clin Nutr, Vol. 84, No. 1, 95-135.

36. Handelman, G.J, Pryor, W.A. 1999. Evaluation of Antioxidant Status in Humans. Dalam Papas, AM (penyunting) "Antioxidant Status, Diet, Nutrition, and Health", hlm47. London: CRC Press.

37. Harsono. 1988. Coaching dan Aspek-Aspek Psikologis dalam Coaching, CV. Tambak Kusuma, Jakarta, Pp 100, 172,174.

38. Hathcock, J., Azzi, A., Blumberg, J., Bray, T., Dickinson, A., Frei, B., et al. 2005. Vitamins E and C are safe across a broad range of intakes. American J of Clin Nutr, Vol. 81, No. 4, 736-745.

39. Heber, D. 2004. Phytochemical Effects beyond Antioxidation. J Nutr. 134: 3143S-3163S

40. Hu, Y, Block, G., Norkus, E.P., Morrow, J.D., Dietrich, M., Hudes, M.. 2006. Relations of glycemic index and glycemic load with plasma oxidative stress markers. American J of Clin Nutr, 84(1):70-76.

41. Ji, L. 1999. Antioxidants and oxidative stress in exercise. Department of Kinesiology, Interdepartmental Program of Nutritional Sciences, and Institute on Aging, University of WisconsinMadison.

42. Ji, L., Leuwenburgh, C., Leichtweis, S., et al. 1998. Oxidative Stress and Aging: Role of Exercise and Its Influences on Antioxidant Systems. Annu of the New York Acad of Sci, 854:102-117.

43. June, H., Mc.Dermott. 2000. Antioxidant Nutrients: Current Dietary Recommendations and Research Update. J Am. Pharm Assoc 40(6); 785-99.

44. Kantr, M., Nolte, L.A., Holloszy.1993. Effect of an antioxidant vitamin mixture on Lipid peroxidation at rest and postexercise. J of Appl Physiol, 74(2):965969.

45. Keren, Clippinger, Robertson, 1986. Aerobics Instructor Manual the Resource for Fitness Professional. Publisher, American Council or Exercise. San Diego California: 209-210.

46. Klaining, J.E., Kamendulis, L.M. 2004. The Oxidative Stress in carcinogenesis (Review). Annu Rev Pharmacol Toxicol. 44; 239-67

47. Klatz, R., Goldman, R. 2000. Theories of aging Melalui < <ttp://www.prolongyouth.com/)> [01/02/08]

48. Kleinsek, D., Dean, W., Harman, D., et all. 2000. Theories of aging. Melalui <http://www.antiagingsystems.com/)> [01/02/08]

49. Lasheras, C., Huerta, J. M., Gonzalez, S.; et al. 2002. Independent and Interactive Association of Blood Antioxidants and Oxidative Damage in Elderly People. Free Radical Research, 36(8): 875 - 882.

50. Leeuwenberg, C, Heinecke, JW. 2001. Oxidative Stress and Antioxidant in Exercise. Curr Medicin Chemist. 8, 829-838.

51. Leeuwenberg, C. , Phaneuf, S. 2001. Apoptosis and Exercise. Med Sci Sports Exerc., Vol. 33, 2001, pp. 393-396.

52. Levine, M., Wang, Y., Padayyaty, S.J. et al. 2001. A New Recommended Dietary Allowance of Vitamin C for Healthy Young Women. Proc Na. Acad. Sci. 98: 9842-9846.

53. Madiyono, B., Moeslichan, S., Sastroasmoro, S., Budiman, I., Purwanto, S.H. 2002. Perkiraan Besar Sampel. Dalam Sastroasmoro S dan Ismael S (penyunting) "Dasar-Dasar Metodologi Penelitian Klinis, Edisi Ke-2", hlm. 269. Jakarta: CV Sagung Seto.

54. Masud, I., 1989. Dasar-dasar Fisiologi Kardiovaskular. EGC. Jakarta.

55. Mathew, D., Fox, L. and Van Hold, K. 1990. Biochemistry. The Benjamin Cummings Publishing Co. Inc. New York: 381-403, 433-569.

56. Mayes, A.P., Murray, K.R., Granner, D.K., et all. 2000, Harper's Biochemistry, W.B. Sounders Company Philadelphia. 25th ed. Pp 115-130

57. Mayne, S.T. 2003. Antioxidant Nutrients and Chronic Disease: Use of Biomarkers of Exposure and 
Oxidative Stress Status in Epidemiologic Research. $J$. Nutr. 133:933S-940S.

58. Mc.Williams, M. 1985. Food Fundamental 4th ed. New York : Macmillan Publishing Company.

59. Nielsen, F., Mikkelsen, B., Nielsen, J., et all. 1997. Plasma Malondialdehyde as Biomarker for Oxidative Stress: Reference Interval and Effects of Life-Style Factors. American Assoc for Clin Chemist, 7:1209-14

60. Ningtias, P.A. 2007. Pengaruh Pemberian $\beta$ Carotene dalam Wortel Kukus (Daucus carota L.) terhadap Kadar Malondialdehid Plasma pada Subjek yang Terpapar Polusi Gas buang Kendaraan Bermotor di Alun-alun Kota Bandung. Tesis. Program Pascasarjana Combined Degree Fakultas Kedokteran Universitas Padjadjaran. Bandung.

61. Noguchi, N., Niki, E. 1999. Chemistry of Active Oxygen Species and Antioxidants. Dalam Papas,A.M.(penyunting),“Antioxidant Status, Diet, Nutrition, and Health", hlm10. London: CRC Press.

62. Padayatty, Sebastian, J, Levine, M. 2001. New Insight Into The Physiology and Pharmacology of Vitamin C. CMAJ. 2001; 164:3.

63. Padayatty, Sebastian, J, Levine, M. 2008. Fruits and Vegetables: think Variety, Go Ahead, Eat. Am J. Clin. Nutr; 87; 5-7.

64. Padayatty, Sebastian, J. 2003. Vitamin C as an Antioxidant: Evaluation of Its Role in Disease Prevention. J of the American Col of Nutr. 22: 18-35.

65. Papas, A.M. 1999. Antioxidant Satus, Diet, Nutrition, and Health. USA : CRC Press.

66. Percival. 2001. Oxidatice Stress andAntioxidants in Exercise.Current Medicinal Chemistry. USA : Bentham Science Publisher

67. Pryor, R.L. 2003. Fruits and vegetables in the prevention of cellular oxidative damage. American J of Clin Nutr, 78(3): 570S-578S.

68. Reilly, T., Secher, N., Snell, P., Williams, C. 1990. Phsyiology of Sport. Chapman \& Hall. London.

69. Riso, P., Pinder, A., Santangelo, A., et al.1999. Does Tomato Consumption Effectively Increase The Resistance of Lymphocyte DNA to Oxidative Damage?. American J of Clin Nutr, 69(4):712-718.

70. Rock, C.L., Lovalvo, J., Emenhiser, C., et.al. 1998. Bioavailability of $\beta$-Carotene Is Lower in Raw than in Processed Carrots and Spinach in Women. The J of Nutr. 128(5): 913-916.

71. Roecker, K., Niess, A.M., Horstmann, T., Striegel, H., Mayer, Dickguth, H.H., Medical \& Science in Sports \& Exercise. Volume 34 number 5. May 2002. Lippincott Williams \& Wilkins. Page 881.

72. Rushall, B. dan Pyke, F.S. 1990. Training for Sport and Fitness, the Mc. Millan Company of Australia Ltd, Pp, 263.

73. Schumacher, Y.O., Schmid, A., Grathwohl, D., Bultermann, D., Berg, A. 2002. Medical \& Science in Sports \& Exercise. Volume 34 number 5. Lippincott Williams \& Wilkins. Page 869.

74. Sentra Informasi IPTEK. 2000. Tanaman Obat Indonesi; Wortel. Jakarta: IPTEK
75. Sherwood, Lauralee. 2006. Human Physiology; From Cell to System. $4^{\text {th }} \mathrm{Ed}$. Belmont CA; Wrisworth Publishing Company.

76. Shi J., Le Maquer. 2000. Lycopene in Tomatoes: Chemical and Physical Properties Affected by Food Processing. J of Critic Rev in Biotech. 20:293-334.

77. Shils, M.E., Ross, C.A. 2006. Modern Nutrition in Health and Disease. 10th edition. Baltimore: Lippincott Williams and Wilkins.

78. Sofia, D. 2003. Antioksidan dan RadikalBebas. Melalui <http://www.chemistry.org/> [01/02/08]

79. Stahl, W., Sies, H. 1992. Uptake of lycopene and its geometrical isomers is greater from heat-processed than from unprocessed tomato juice in human. $J$ of Nutr. 122:2161-2166.

80. Stang, J., Story, M. 2005. Nutrition screening,assessment, intervention.Melalui $<$ http://www.epi.umn.edu/> [01/02/08]

81. Stocker, R., Keaney, JF., Jr. 2004. Role of Oxidative Modifications in Atherosclerosis (Review). Physiol Rev. $84 ; 1381-478$

82. Sudjana. 1992. Metode Statistika, Edisi 5, Penerbit, Tarsito, Bandung, 261- 466.

83. Trevisan, M., Browne, R., Ram, M., Muti, P., Freudenheim, J., Carosella, M and Amstrong, D. 2001. Correlates of Markers of Oxidative Status in the General Population. Am. J. Epidemiol. 154(4):348-56

84. Van Het Hof, K. H., West, C. E., Weststrate, J. A., Hautvast, G. 2000. Dietary Factors That Affect the Bioavailability of Carotenoids. J of Nutr. 130:503506.

85. Whitney, E., Rolfes, S. R. 2005. Understanding Nutrition. USA : Thomson Wadsworth

86. Whyte, Greg. 2005. The value of anti-oxidants:an expert shifts the evidence. Melalui: http://www. The value of anti-oxidant an expert sifts the evidence.htm

87. Wilmore, H.J. \& Costill, L.D. 1994. Physiology of Sport and Exercise, USA: Human Kinetics; 83.

88. Winarsi, H., M.S., 2007. Antioxidan Alami dan Radikal Bebas. Yogyakarta: Penerbit Kanisius.

89. Wirya, I. W. 2006. Pemberian asam askorbat pada pelari sprint $200 \mathrm{~m}$ untuk meredam pembentukan radikal bebas yang diukur dari penurunan malondialdehid dan laktat plasma. Tesis. Universitas Lampung.

90. Wu, G., Yang, S., Fang, YZ. 2002. Free Radicals, Antioxidants and Nutrition. J Nutr. 18 (10); 872-9.

91. Zoppi, R.C., Hohl, R., Da ilva, F., et al. Mei 21, 2006. Vitamin C and E Supplementation Effecs in Profesional Soccer Players under Regular Training. $J$ of the Intl Soc of Sports Nutr.3:100-113. 